\title{
Pelletization of Seeds of Raphanus sativus L. cv. Redondo Gigante with Graphite for Germination under Water Stress Conditions
}

\author{
Nobel Penteado Freitas ${ }^{1^{*}}$ and Massanori Takaki ${ }^{2}$ \\ ${ }^{1}$ Núcleo de Estudos Ambientais - UNISO, Sorocaba - SP, Brasil; ${ }^{2}$ Departamento de Botânica - UNESP CP 199 - Rio \\ Claro CEP 13506-900 - SP, Brazil
}

\begin{abstract}
The effect of water stress on germination of radish seeds is dependent on the presence of light. The effect of pelletization of radish seeds with powdered graphite on the tolerance to water stress under light was analysed. White light and far-red lights were filtered by graphite increasing slightly the tolerance of pelleted seeds to water stress of $0.77 \mathrm{MPa}$. Although red light also inhibited seed germination the graphite had no effect. We propose the pelletization of seeds of Raphanus sativus, at least in cv redondo gigante with graphite as a pratice before planting to increase the tolerance to water stress.
\end{abstract}

Key words: pelletization, Raphanus sativus, seed germination, water stress

\section{INTRODUCTION}

The white light influences the germination of seeds promoting or inhibiting the process through the pigment phytochrome. This promotion of the germination is due to the low fluence where the R/FR reversibility occurs. The inhibition of the germination by white light is due to the high fluence, where the inhibition is dependent of the fluence rate and of the cycling of the phytochrome forms (Bartley \& Frankland, 1983). The germination of seeds can also be inhibited or delayed when the availability of water is not enough (Freitas \& Takaki, 1992).

Seeds of Raphanus sativus L. are light insensitive, but under water stress conditions the germination is inhibited by white light (Guardia et al., 1987). The appearance of the sensitivity to the light under conditions of water stress of was described by Thanos and Mitrakos (1979) in caryopses of Zea mays and in seeds of Lycopersicum lycopersicom by Georghiou et al. (1982). The induction of the sensitivity to the light in Raphanus sativus under water stress was described by Ladeira et al. (1987), suggesting the action of phytochrome in the germination process. Niedzwiedz-Siegen and Lewak (1988, 1989) working with Trifolium repens observed the dependence of the germination to light in conditions water under stress, suggesting that the phytochrome is responsible for the inhibition of the germination. The germination of seeds in Oryza sativa is also influenced by water potential of the medium. Inhibition of germination was observed under continuous white light (Takaki, 1990). Guardia et al. (1987) showed that the sensitivity to white light induced by water stress in Raphanus sativus is dependent of the irradiance, suggesting the involvement of phytochrome under high irradiance response. Freitas and Takaki (1992) confirmed the involvement of the phytochrome controlling the process of germination in seeds of Raphanus sativus under water stress conditions. The pelletization of seeds is a common pratice using clay with Rhizobium in leguminous as Phaseolus

* Author for correspondence 
vulgaris (Jansen et al., 1994) or with nutrients and herbicides (Heuijbroek \& Huijbregts, 1995)

This work describes the use of the pelletization of seeds of Raphanus sativus with powdered graphite for the increase of the tolerance to water stress under light conditions.

\section{MATERIAL AND METHODS}

The seeds of Raphanus sativus L. cv. redondo gigante (Corradini, Brazil), utilized in the present work were acquired in a local shop. For each treatment, four sets of 30 seeds of Raphanus sativus were placed in $60 \mathrm{~mm}$ diameter Petri dishes, with two layers of filter paper soaked with distilled water or solution of polyethyleneglycol 6000 (PEG). The different water potentials were obtained with different concentrations of PEG (Michel, 1983). Seeds with at least $2 \mathrm{~mm}$ long roots were considered as germinated. Seeds germinated in darkness were counted under dim green safety light (Kendrick \& Frankland, 1969).

The white light was obtained with the aid of day light fluorescent lamps (Philips 15W), the red light was obtained by covering Petri dishes with two layers of red cellophane paper under fluorescent lamps and the far-red light was obtained by two layers each of red and blue cellophane under incandescent light (Sylvania 25W, Brazil). The curves of fluence responses were obtained as described by Guardia et al. (1987).

Seed pellets were obtained by the use of $0.1 \%$ aqueous solution of Arabic gum and powdered graphite instead of clay (Siqueira, 1988). The seeds were humidified slightly in solution of Arabic gum and later shaken in a plastic box with powdered graphite, until being formed a fine and homogeneous layer on the seeds. The Gompertz regression function was used for making of the fluence-response curves (Trexler et al. 1988) using AAC PC program (Calbo et al., 1989).

\section{RESULTS AND DISCUSSION}

Seeds of Raphanus sativus L. cv redondo gigante is insensitive to the light in the germination process when soaked in water, with high percentage germination under both continuous white light and darkness as observed by McDonough (1967) and by Ladeira et al. (1987).

The curves of fluence response shows that under $0.77 \mathrm{MPa}$ the increase in the light fluence promotes inhibition of germination, but the pelletization of seeds resulted in slight increase in the tolerance to water stress under white light (figure 1A). The control without water stress pelletization has no effect on light effect. Red light also is responsible for inhibition of germination and pelletization had no effect (figure 1B). The far red light presented high inhibition of germination (figure 1C) indicating the phytochrome involvement in the process through the high irradiance response as described by Freitas and Takaki (1992). The same effect of light fluence on inhibition of germination in seeds of Phaseolus vulgaris cv. carioca was described by Lopes and Takaki $(1987,1988)$.

Schopfer and Plachy (1993) working with radish seeds proposed that light inhibition of seed germination, under water stress, is due to the maintainance of a high threshold of cell wall extensibility in the embryo, not observed in dark maintained seeds.

Our results indicated that the pelletization with powdered graphite resulted in the decrease in the light fluence that reached the seed decreasing the inhibitory effect of white and far red lights. The pelletization of seeds with herbicides and inseticides to decrease infection of seedlings and use of Rhizobium mixed with clay in leguminous seeds has been common practice (Jansen et al., 1994; Heuijbroek \& Huijbregts, 1995). Because a fine layer of graphite induced increase in the tolerance to water stress we propose the pratice of pelletization with more layers of graphite before planting of seeds of Raphanus sativus cv. Redondo gigante in soil. 
A

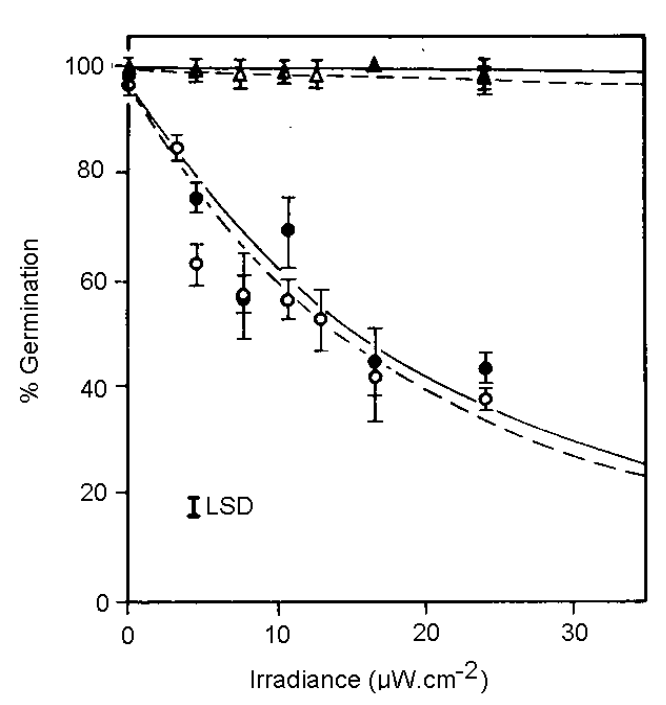

B

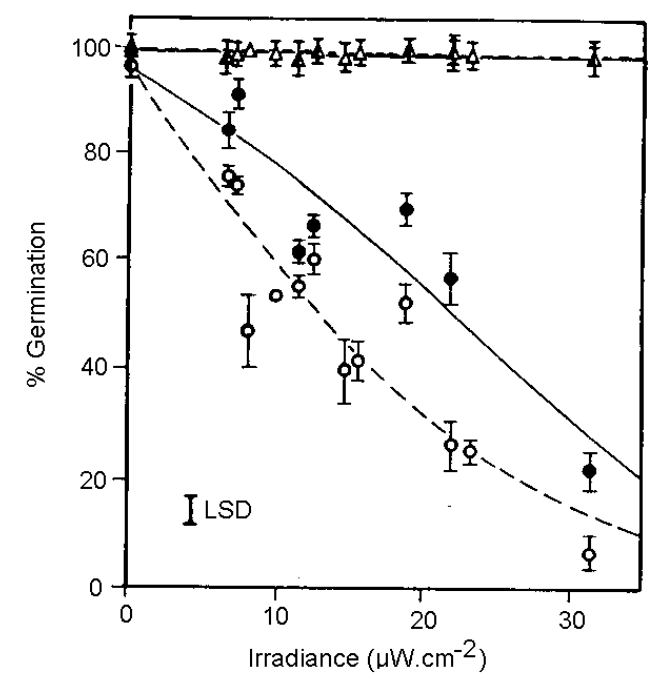

C

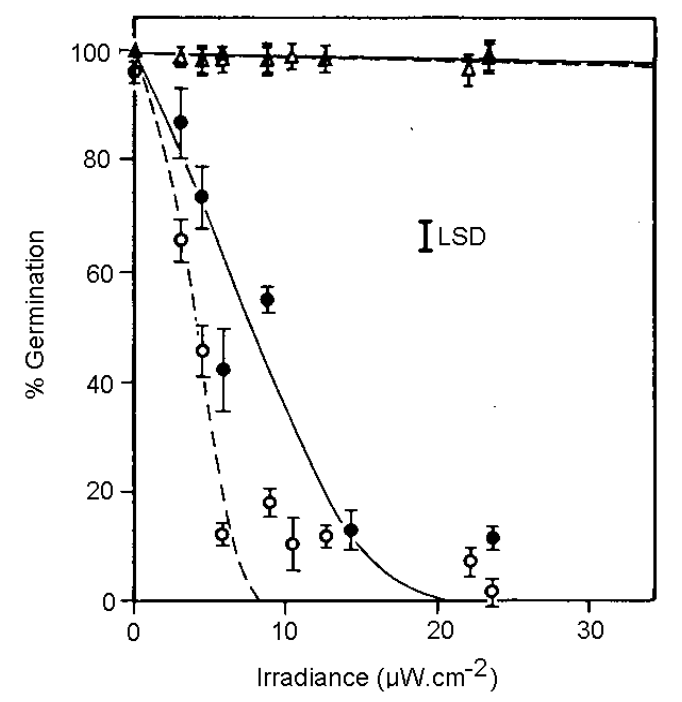

Figure 1. Effect of interaction of water stress of -0.77MPa and fluence of white light (A), red light (B) and far-red light (C) on seed germination in Raphanus sativus L. cv redondo gigante. - - pelleted seeds under water stress and - not pelleted seeds under water stress; - $\boldsymbol{-}$ - pelleted seeds under no water stress and - - not pelleted seeds under no water stress. (-) pelleted seeds and (---) not pelleted seeds Bars on the symbol= standard error of mean also LSD bar at $5 \%$ probability is shown in the figures.

\section{RESUMO}

O efeito do estresse hídrico é dependente da presença de luz em sementes de rabanete. $\mathrm{O}$ efeito da peletização com grafite em pó foi analisado. Luz branca e vermelho-extremo são filtradas pelo grafite aumentando parcialmente a tolerância ao estresse hídrico de $-0,77 \mathrm{MPa}$ em sementes peletizadas. Embora a luz vermelha também iniba a germinação em condições de estresse a peletização não teve efeito. Nós propomos a peletização de sementes de Raphanus saivus L. cv. redondo gigante como uma prática antes do plantio para aumentar a tolerância ao estresse hídrico.

\section{ACKNOWLEDGEMENTS}


N.P.F. was supported by $\mathrm{CNPq}$ scholarship and MT is a CNPq Research fellow. Work aided by grants from CNPq and FAPESP.

\section{REFERENCES}

Bartley, M.R.; Frankland, B. Analysis of dual role of phytochrome in the photoinhibition of seed germination. Nature, 300, 750-752, 1982.

Calbo, A.G.; Whistles, W.L.C. ; Towers, B.C. Adjustment of non linear functions of growth. Revista brasileira de Fisiologia Vegetal, 1, 9-18, 1989.

Freitas, N.P.; Takaki, M. Phytochrome controlled seed germination in light insensitive seeds of Raphanus sativus L. cv. redondo gigante. Brazilian Archives of Biology and Technology, 35, 609-612, 1992.

Georghiou, K.; Thanos, C.A.; Tafas, T.P.; Mitrakos, K. Tomato seed germination, osmotic treatment and far red inhibition. Journal Experimental of Botany, 33, 1068-1075, 1982.

Guardia, M.C.; Caramello, K.A.; Takaki, M. Osmotically induced light sensitivity in seeds of Raphanus sativus L. Brazilian Archives of Biology and Technology, 30, 665-670, 1987.

Heuijbroek, W.; Huijbregts, A.W.M. Fungicides and insecticides applied to pelleted sugar-beet seeds. 2 . Control of pathogenic fungi in soil. Crop protection, 14, 363-366, 1995.

Jansen, J.P.; Schiffers, B.C.; Mathot, P.; Brakel, J. Use of bacteria protections in pelleting for preinoculation of bean-seeds (Phaseolus vulgaris L.). Seed Science and Technology, 22, 329-336, 1994.

Kendrick, R.E.; Frankland, B. Photocontrol of germination in Amaranthus caudatus. Planta, 85, 326329, 1969.

Ladeira, A.M.; Guardia, M.C.; Takaki, M. Manipulation of seed germination in Plantago tomentosa Lam. and Raphanus sativus L Seed Science and Technology, 15, 55-63, 1987.

Lopes, V.B.; Takaki, M. Seed germination in Phaseolus vulgaris L. I. Osmotic effeect on light sensitivity.
Brazilian Archives of Biology and Technology, 30, 641-647, 1987.

Lopes, V.B.; Takaki, M. Seed germination in Phaseolus vulgaris L. II. Effect of water potential and photoperiod. Brazilian Archives of Biology and Technology, 31, 307-312, 1988.

McDonough, W.T. Dormant and non dormant similar germination response when osmotically inhibited. Nature, 214, 1147-1148, 1967.

Michel, B.E. Evaluation of water potentials of solutions of polyethyleneglycol 8000 both in the absence and presence of other solutes. Plant Physiology, 72, 6670, 1983.

Niedzwiedz-Sielgien, I.; St, Lewak. Phytochrome invilvement in inhibition of germination of white clover seeds at low temperature. Acta Physiologiae Plantarum, 10, 301-306, 1988.

Niedzwiedz-Siegien, I.; St, Lewak. Photoinhibition of white clover seed germination attn low water potential. Physiologia Plantarum, 76, 53-56, 1989.

Schopfer, P. ; Plachy, C. Photoinhibition of radish (Raphanus sativus L.) seed germination: control of growth potential by cell-wall yielding in the embryo. Plant, Cell and Environment, 16, 223-229, 1993.

Siqueira, J.O. Biotecnologia do solo: fundamentos $e$ perspectivas. Brasília: MEC. Abeas; ESAL, FAEPE, 1988.

Takaki, M. Effect of water stress on seed germination and seedling growth in Oryza sativa L. Biologia Plantarum, 32, 238-240, 1990.

Thanos, C.A.; Mitrakos, K. Phytochrome-mediated germination control of mayze cariopses. Planta, 146, 415-417, 1979.

Trexler, J.C.; McCulloch, C.E. ; Travis, J. How can the functional response best be determined? Oecologia, 76, 206-214, 1988. 